\title{
Production and structural, electrical and magnetic characterization of a composite material based on powdered magnetite and high density polyethylene
}

\author{
Andrés Orlando Garzón 1,*, David A. Landínez ${ }^{1}$, Jairo Roa-Rojas', \\ Fabio. E. Fajardo-Tolosa ${ }^{2}$, Gabriel Peña-Rodríguez ${ }^{3}$, C.A. Parra-Vargas ${ }^{4}$
}

\begin{abstract}
${ }^{1}$ Grupo de Física de Nuevos Materiales, Departamento de Física, Universidad Nacional de Colombia, Bogotá, Colombia ${ }^{2}$ Grupo de Estudios de Materiales - GEMA, Departamento de Física, Universidad Nacional de Colombia, Bogotá, Colombia

${ }^{3}$ Grupo de Investigación en Tecnología Cerámica, Universidad Francisco de Paula Santander, San José de Cúcuta, Colombia

${ }^{4}$ Grupo de Física de Materiales, Universidad Pedagógica y Tecnológica de Colombia, Escuela de Física, Tunja, Colombia
\end{abstract}

\begin{abstract}
This work describes the production and characterization of a composite material based on magnetite filled HDPE, which is commonly known for its magnetic properties. Composites of this kind are used in different applications such as microwave absorption, transducers and biomedical applications like drug delivery, organs tagging, etc. The samples were produced according to different volume ratios of magnetite and HDPE. The semiquantitative analysis conducted by XRD revealed the presence of hematite within the mineral magnetite used as a filler in the composites. The crystallinity degree was calculated through X-ray diffraction tests. The XRD results showed how there is an amorphous-crystalline transition due to the magnetite increasing content. The crystallinity percent $\left(\chi_{c}\right)$ for samples filled with $40 \%$ of magnetite volume was $90 \%$ while the $\left(\chi_{c}\right)$ for samples filled with $10 \%$ of magnetite volume was $80 \%$. Which may be related to the increased magnetite particles into the plastic matrix for reinforcement contents up to $30 \%$ by volume, as evidenced in the images obtained through scanning electron microscopy (SEM). The samples were electrically characterized through volume resistivity measurements and electric polarization. The results showed that for ratios less than the $20 \%$ of magnetite there is no substantial reduction in the resistivity of the composite samples compared to the unfilled HDPE samples, but for magnetite ratios above $30 \%$ the composite samples showed a substantial reduction of six orders of magnitude in their volumetric resistivity. The electric polarization showed how the composite material undergoes a transition, going from an insulating material (for samples with $10 \%$ of magnetite volume) to a resistive material where the current and voltage are in phase (for samples with $30 \%$ and $40 \%$ of magnetite volume). The magnetization curves showed that the saturation magnetization (from 17,3 to 60,5 emu/g) and remanence (from 0,94 to $5 \mathrm{emu} / \mathrm{g}$ ) increase in samples with high magnetite contents. The presence of the hematite phase in the samples could have affected the magnetization saturation and the remanence values in the hysteresis curves. Magnetization curves as a function of temperature showed the Verwey samples transition around the $120 \mathrm{~K}$ and confirmed that the magnetization increases as the magnetite volume within the matrix increases. (c) 2017. Acad. Colomb. Cienc. Ex. Fis. Nat.
\end{abstract}

Key words: High density polyethylene; Magnetite; Plastic composites, Structural properties electric properties; Magnetic properties.

Producción y caracterización estructural, eléctrica y magnética de un material compuesto a base de magnetita pulverizada y polietileno de alta densidad.

\section{Resumen}

Se describe la producción y caracterización de un material compuesto basado en matrices de polietileno de alta densidad (HDPE) reforzadas con magnetita pulverizada. Compuestos de este tipo son usados para diferentes aplicaciones como la fabricación de escudos de absorción electromagnética, transductores, entrega focalizada de medicamentos, marcación de órganos, etc. Las muestras fueron producidas de acuerdo a diferentes proporciones en volumen de magnetita y HDPE. Los análisis semicuantitativos llevados a cabo por medio de DRX dejan en evidencia la presencia de hematita al interior de la magnetita mineral usada como refuerzo del compuesto. El porcentaje de cristalinidad de los compuestos se calculó a través de difracción de rayos X. Los resultados de la difracción mostraron una transición amorfo-cristalino del compuesto, debida al creciente contenido de magnetita al interior de la matriz. El porcentaje de cristalinidad $\left(\chi_{c}\right)$ de las muestras reforzadas con un $40 \%$ en volumen de magnetita fue del $90 \%$ mientras que para las muestras reforzadas con el $10 \%$ en volumen la cristalinidad fue del $80 \%$. Esto puede

\footnotetext{
*Corresponding autor:

Andrés Orlando Garzón, aogarzonp@unal.edu.co; Received: October 14, 2016; Accepted: March 29, 2017
} 
estar ligado a la mayor proliferación de partículas de magnetita al interior de la matriz plástica para contenidos de refuerzo superiores al 30\% en volumen, tal y como se evidenció en las imágenes obtenidas a través de microscopía electrónica de barrido (SEM). Las muestras fueron eléctricamente caracterizadas a través de medidas de resistividad volumétrica y polarización eléctrica. Los resultados mostraron que para proporciones del refuerzo de magnetita iguales o inferiores al 20\% no hay una reducción substancial en la resistividad de los compuestos comparada con la del polietileno sin reforzar. En cambio, para proporciones de magnetita iguales o superiores al 30\% en volumen los compuestos muestran una reducción en la resistividad de hasta seis ordenes de magnitud. La polarización eléctrica deja en evidencia como el material compuesto presenta una transición al pasar de ser completamente aislante (10\% en volumen de magnetita) a ser un material resistivo donde la corriente y el voltaje se encuentran en fase (muestras reforzadas con 30\%-40\% de volumen de magnetita). Las curvas de histéresis magnética en función del campo aplicado muestran un incremento constante en la magnetización de saturación (de 17,3 a 60,5 emu/g) y en la magnetización remanente (de 0.94 emu/g a 5 emu/g), al aumentarse el contenido de magnetita en las muestras. La presencia de hematita en las muestras pudo haber afectado los valores de la magnetización de saturación y de remanencia en las curvas de histéresis magnética. Las curvas de magnetización en función de la temperatura dejan en evidencia la transición de Verwey de la magnetita alrededor de los $120 \mathrm{~K}$, a la vez que confirman el aumento en la magnetización de las muestras conforme el contenido del refuerzo aumenta al interior de la matriz. C 2017. Acad. Colomb. Cienc. Ex. Fis. Nat.

Palabras clave: Polietileno de alta densidad; Magnetita; Materiales plásticos compuestos; Propiedades estructurales; Propiedades eléctricas; Propiedades magnéticas.

\section{Introduction}

This paper aims to produce a composite material based on high density polyethylene (HDPE) with different proportions of powdered magnetite $\left(\mathrm{Fe}_{3} \mathrm{O}_{4}\right)$. Such composites have been subject of research because of its economy, its technological applications and also because they are environmentally friendly since some recycled plastic may be used for their production. Composites of this kind are used in different applications such as ferrite cores, electromagnetic shielding, transducers, and in some biomedical applications like drug delivery, organs tagging, etc. To produce this kind of composites fillers in different shapes are used: Particles, fibers or sheets in combination with matrices made of thermoplastic or thermoset polymers. The most common methods used to produce these plastic composites are the blending and cold blending methods. The last method is commonly known for its use with thermoset matrices like epoxy resins while the melt blending method is used with thermoplastic matrices such as the HDPE. In this work, a single screw extruder machine was used to produce the HDPE/magnetite composites following the melt blending method.

During the last decade, many studies have tried to improve the performance of plastic composites for specific applications, adding to the polymeric matrix different kinds of reinforcements like fibers and particulate materials such as silicates, hard and soft ferrites like the magnetite: abundant material, economical and easy to achieve due to the plenty number of mines found throughout Colombia, mainly those that are located in Huila and Cundinamarca. Additionally, the HDPE is one of the most used polymers in the world due to its low cost, ease of processing and good performance, in addition to being known as a reusable thermoplastic. By the addition of silicates, such as montmorillonite some researchers have successfully enhanced the mechanical properties of some polymeric matrices; these composites can be used as building block for constructions (Rosales, et al., 2006). In other works, the addition of some minerals, like the graphite or magnetite (in different proportions) into the polymeric matrix, have allowed researchers to study the percolative properties of the composite material, these kinds of studies can be useful for the design of technological gadgets: heat sinks or packages for electronic devices with electromagnetic shielding (Panwar, Sachdev \& Mehra, 2007; Weidenfeller, Höfer \& Schilling, 2002). Although the use of magnetite in thermoplastic and thermoset matrices is relatively new, these composites have been implemented in the biomedical industry: Stents that can be able to change their shape in the presence of magnetic fields (Razzaq, Anhalt, Frormann \& Weidenfeller, 2007; Zheng, et al., 2009). Some polymers like the polymethyl methacrylate filled with magnetite can also be used in pharmaceutical applications including targeted drug delivery, tissue reconstruction and tumor treatments (Hamoudeh, et al., 2007; Harris, et al., 2003), primarily because of the low cytotoxicity of the magnetite (Zhao, Saatchi \& Häfeli, 2009; Zhang, Rana, Srivastava \& Misra, 2008).

This work is an innovative example that raises the possibility of generating new products and contributions to the materials technology using economical and easily obtainable raw materials or in the case of magnetite to take advantage of an abundant and natural resource in Colombia.

After the samples production through the melt blending method, the crystallinity degree, resistivity, electrical polarization, and magnetization properties were studied. It was expected to achieve a composite with the mechanical properties (low weight and excellent machinability) of the polymers, along with the conductive and ferrimagnetic properties of the magnetite. This composite can be used for transducers, electromagnetic shielding or for the development of biomedical products, using economical and reusable raw materials. 


\section{Experimental procedures}

Samples preparation. With the magnetite $\left(\mathrm{Fe}_{3} \mathrm{O}_{4}\right)$, and HDPE density, the samples were prepared with different volume ratios of the precursors, as it is shown in table 1.

The samples were produced using a single screw extruder machine, with three heating zones and an extrusion rate of $42 \mathrm{rpm}$. After the extrusion, the samples were cutted using a diamond disk at low speeds. For each sample, two specimens were prepared. Experimentally it was found the extrusion temperatures and times of pure HDPE and the other samples, table 2. In each case the machine was preheated for 15 minutes. There was a slight increase in the M35 and M40 temperatures and extrusion times, due to the growth of the total material density that flew around the screw and it was associated with higher ratios of magnetite. Hence, through some experimental tests, it was found that as the extrusion temperature raised, the flow rate of the mix is increased.

Measurements. The composites crystallinity degree was studied using the X-ray diffraction (XRD) technique (X'Pert PRO MPD panalytical) with CuK $\alpha 1$ radiation (1.540598 $\AA$ ) in the $2 \theta$ range $10-70^{\circ}$, in steps of $0.02^{\circ}$. The semiquantitative analysis of the phases presented in the samples was conducted through the use of X'Pert High Score software version 2.1.2 developed by PANalytical B.V. with the material database 2004 PDF 2.

The morphology of the samples was observed through SEM micrographs (FEI Quanta 200). The volume resistivity measurements were conducted using an Electrometer / High Resistance Meter (Keithley 6517A with the MODEL 8009 test fixture) a bias voltage of $25 \mathrm{~V}$ was applied during 60 seconds to each sample. The electric polarization measurements were

Table 1. Samples identification and volume raw materials ratios.

\begin{tabular}{ccc}
\hline Sample ID & \%Vol Fe3O4 & \%Vol HDPE \\
\hline $100 \%$ HDPE & 0 & 100 \\
M10 & 10 & 90 \\
M20 & 20 & 80 \\
M30 & 30 & 70 \\
M35 & 35 & 65 \\
M40 & 40 & 60 \\
\hline
\end{tabular}

Table 2. Extrusion temperatures and times for each sample.

\begin{tabular}{ccccc}
\hline \multicolumn{2}{c}{ Extrusion temperatures $\left({ }^{\circ} \mathbf{C}\right)$} & $\left(\mathbf{\pm 1 . 5 ^ { \circ } \mathbf { C } )}\right.$ & Extrusion times \\
\cline { 1 - 4 } Sample ID & Zone $\mathbf{1}$ & Zone $\mathbf{2}$ & Zone $\mathbf{3}$ & $(\mathbf{m i n})$ \\
\hline 100\%HDPE & 180 & 180 & 160 & $5-6$ \\
M10 & 270 & 270 & 260 & $7-8$ \\
M20 & 270 & 270 & 260 & 10 \\
M30 & 270 & 270 & 260 & 11 \\
M35 & 280 & 280 & 260 & $11-12$ \\
M40 & 280 & 280 & 260 & $11-12$ \\
\hline
\end{tabular}

carried out in a ferroelectric tester of Radiant Technologies (model N1P-HVA10-OP110) which uses the Vision Software version 3.1. These measurements were made with different voltage ranges because the relationship between the increasing ratio of magnetite in the samples and higher conductivity. As a result, the equipment integrity could be affected. The magnetic properties were measured using a vibrating sample magnetometer (VersaLab 3 Tesla, Cryogenfree PPMS of Quantum Design) the variable applied field was \pm 3 Tesla. Then, applying constant fields of 0.3 Tesla, magnetization and susceptibility measurements as a function of the temperature (50-300K) were taken.

\section{Results and discussion}

$X \boldsymbol{R D}$. Prior to the samples synthesis, the different phases that comprise the powder magnetite used in the composites production were semiquantitatively identified. Through the X'Pert HighScore software version 2.1.2, it was found that the magnetite is composed of two different phases: Magnetite and Hematite, with an approximate weight percent of $87.1 \%$ and $12.9 \%$ respectively, figure 1 . Hematite $\left(\mathrm{Fe}_{2} \mathrm{O}_{3}\right)$ is an iron oxide, with high corrosion resistance, low cost, semiconductor properties, no toxicity, is commonly known as antiferromagnetic materials (Tadić, et al., 2011), but it is characterized to be chemically more stable than the magnetite. In Natural magnetite ore deposits it is common to find traces of hematite (Otake, Wesolowski, Anovitz, Allard \& Ohmoto, 2007). The $\mathrm{X}$ ray diffractogram of pure $\mathrm{Fe}_{3} \mathrm{O}_{4}, \mathrm{HDPE}$, and the composites with different filler ratio content are shown in figure 2.

The hematite characteristic reflections are: $24.182^{\circ}$, $33.205^{\circ}, 35.67^{\circ}, 39.341^{\circ}, 40.910^{\circ}, 50.533^{\circ}, 54.149^{\circ}$, and $72.065^{\circ}$ while the magnetite characteristic reflections are: $18.28^{\circ}, 30.08^{\circ}, 35.43^{\circ}, 37.071^{\circ}, 43.070^{\circ}, 53.43^{\circ}, 56.95^{\circ}$,

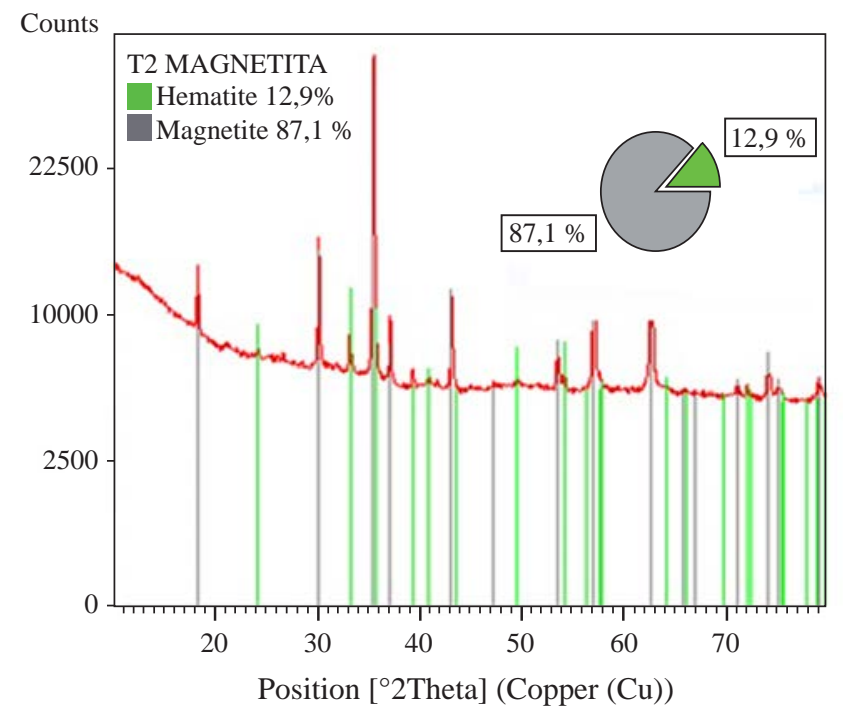

Figure 1. Weight percentage of the phases that compose the magnetite powder used for the samples synthesis. 
Rev. Acad. Colomb. Cienc. Ex. Fis. Nat. 41(159):154-167, abril-junio de 2017 doi: http://dx.doi.org/10.18257/raccefyn.422

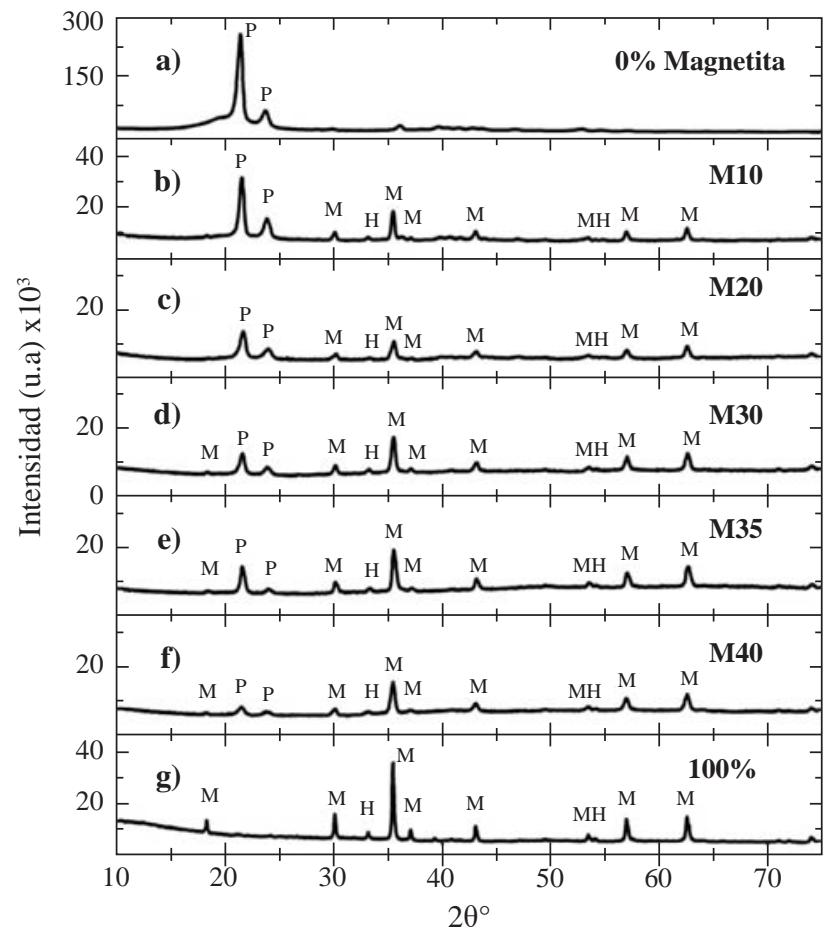

Figure 2. Diffraction patterns for all samples with different volume percentages of magnetite powder b) $10 \%$ c) $20 \%$ d) $30 \%$ e) $35 \%$ f) 40\%. Diffraction patterns of: a) 100\% HDPE, and g) $100 \%$ magnetite.

$62.546^{\circ}, 70.95^{\circ}$, and $73.992^{\circ}$, figure 2 . The magnetite has a face-centered cubic system, whereas the hematite belongs to a hexagonal crystal system.

Figure 2 shows a steady decrease in the characteristic of the peaks' intensity of the HDPE located in $21.419^{\circ}$ and $23.707^{\circ}$ in all samples, as well as the amorphous region $(2 \theta$ $: 17^{\circ}-21^{\circ}$ ). These peaks reduced dramatically in the M35 and M40 diffractograms (figure 2e and figure $2 \mathrm{f}$ respectively). Moreover, a gradual increase occurred in the characteristic peaks of the crystalline phases (hematite and magnetite): $33.205^{\circ}, 35.43^{\circ}, 37.071^{\circ}, 43.070^{\circ}, 56.95^{\circ}$, and $62.546^{\circ}$.

It can be concluded that there was an amorphouscrystalline transition due to the magnetite increasing content. The amorphous region size and characteristic HDPE peaks intensity decreased, while the quantity of crystalline peaks and its intensity increased. This is sustained through the calculation of the crystallinity percent for each sample $\left(\chi_{c}\right)$, table 4. The HDPE and magnetite never reacted with each other; hence, did not create either a new phase or new peaks, figure 2 .

The semiquantitative analysis of each sample showed the variation in weight percentages of the contained phases (hematite and magnetite). This behavior helps to explain the magnetic properties of the composites. Table 3 shows the results for the semiquantitative analysis for each composite.

As it is shown in table 3, the magnetite and hematite phases are present in all composite samples, since these comprises the magnetite powder used as raw material.
Production and characterization of a composite material based on $\mathrm{fe}_{3} \mathrm{O}_{4}$ and hdpe.

M10 and M20 samples contain a higher hematite weight percentage (34.1\%-39.9\%), and lower magnetite phase content $(65.9 \%-63.1 \%)$, regarding the magnetite powder used as precursor, which has a weight percentage of $12.9 \%$ and $87.1 \%$ respectively in each phase. This confirms the increasing weight percentage of the hematite phase for the samples with less ratio of magnetite powder, figure $1 \mathrm{~S}$, https://www.raccefyn.co/index.php/raccefyn/article/download SuppFile/422/1991. The increased amount of hematite is directly related to the production stage in which several factors such as the weight of the raw materials and the extrusion temperatures, tables 1-2, can affect the samples properties.

Magnetite to hematite transformation and vice versa is very common in nature because these two minerals are abundant sources of iron in the earth. In rocks where iron oxides are produced, mutual substitution between magnetite and hematite is carried out (Mücke \& Cabral, 2005) through redox reactions and hydrothermal reactions in aqueous media (Otake, et al., 2007). Hematite $\left(\mathrm{Fe}_{2}{ }^{\mathrm{III}} \mathrm{O}_{3}\right)$ contains only iron with a $\mathrm{Fe}^{\mathrm{III}}$ oxidation state (ferric) which makes it stable in the presence of oxygen. On the other hand, magnetite $\left(\mathrm{Fe}^{\mathrm{II}} \mathrm{Fe}_{2}{ }^{\mathrm{III}} \mathrm{O}_{4}\right)$ contains two oxidation states of iron in $\mathrm{Fe}^{\mathrm{III}}$ and $\mathrm{Fe}^{2 \mathrm{II}}$ (ferric and ferrous) being more unstable in the presence of oxygen, producing its transformation to hematite through an oxidation reaction, as it is shown in the following equation (Otake, et al., 2007):

$$
2 \mathrm{Fe}_{3} \mathrm{O}_{4}(\mathrm{Mt})+0.5 \mathrm{O}_{2} \rightarrow 3 \mathrm{Fe}_{2} \mathrm{O}_{3}(\mathrm{Hm})
$$

The thermal process during the extrusion that induces the magnetite oxidation to hematite is carried out at higher rates in those samples that contain less powdered magnetite

Table 3. Weight percentages of the phases present in the samples according to the XRD semiquantitative analysis.

\begin{tabular}{ccc}
\hline Sample ID & $\begin{array}{c}\text { Hematite \%Weight } \\
\text { according XRD }\end{array}$ & $\begin{array}{c}\text { Magnetite \%Weight } \\
\text { According XRD }\end{array}$ \\
\hline M10 & 34.1 & 65.9 \\
M20 & 39.9 & 63.1 \\
M30 & 24.7 & 75.3 \\
M35 & 20.8 & 79.2 \\
M40 & 20.1 & 79.9 \\
100\% Magnetite & 12.9 & 87.1 \\
\hline
\end{tabular}

Table 4. Percent crystallinity of each sample

\begin{tabular}{|c|c|}
\hline$\%$ Vol of magnetite in each sample & $\% \chi c$ of each sample \\
\hline 0-HDPE & 73 \\
\hline 10 & 80 \\
\hline 20 & 85 \\
\hline 30 & 88 \\
\hline 35 & 89 \\
\hline 40 & 90 \\
\hline 100 & 98.8 \\
\hline
\end{tabular}


(table 3 and figure 1S, https://www.raccefyn.co/index.php/ raccefyn/article/downloadSuppFile/422/1991). Since a fluid mixture within the extruder (M10 and M20 samples) can reach a more homogeneous heating along the screw during the process; thus, it promotes the powdered magnetite oxidation reaction. In contrast, mixtures with higher ratio of powdered magnetite (M30-M40) are less fluid due to the greater weight of solid material added, and thereby the homogeneous heating is lower.

The XRD technique is frequently used to characterize semicrystalline polymers in order to assess their crystallinity degree, defects and preferential orientations. In semicrystalline polymers two different phases are mainly distinguished: The crystalline and the amorphous phase. Thus, the X-ray diffraction is the simplest technique for measuring the polymeric materials crystalline fraction at room temperature. For the degree of crystallinity determination, numbers of $\mathrm{x}$-ray diffraction methods are reported and practiced. The most common method is the Wide-Angle X-ray Diffraction (WAXD) method and it is used in the present work.

The diffraction pattern of each sample is divided in two zones: Crystalline and amorphous. The intensity of the diffracted beam from crystalline part $\left(\mathrm{I}_{\mathrm{c}}\right)$ is the area under the sharply resolved peaks, which in this case includes two HDPE main peaks $\left(21.419^{\circ}\right.$ and $\left.23.707^{\circ}\right)$, as well as those peaks contributed by the hematite and magnetite phases. The intensity of the diffracted beam from amorphous part $\left(\mathrm{I}_{\mathrm{a}}\right)$ is the remaining area under curve above background. For all diffraction patterns the amorphous region is given by the HDPE amorphous zone $\left(2 \theta: 17^{\circ}-21^{\circ}\right)$. Finally, the $\% \chi_{c}$ or percent crystallinity is calculated as the ratio between the crystalline peaks area $\left(\mathrm{I}_{c}\right)$ in the total area of the diffraction pattern $\left(I_{c}+I_{a}\right)$ in which the diffracted beam is more intense:

$$
\% \chi_{c}=\frac{\left(I_{c}\right)}{\left(I_{c}+I_{a}\right)} * 100
$$

To calculate the areas under the peaks of the crystalline region, as the relief of the amorphous region in all samples, Lorentzian functions were used. Crystallinity percentages are shown in Table 4.

SEM. Images of all composite samples were taken, as well as the raw materials in order to assess the material morphology, dispersion and homogeneity of the particulate material into the polymer matrix.

Through SEM images it is not possible to distinguish the morphological differences between hematite and magnetite; both phases are present in the powder used as raw material as it was previously demonstrated by the XRD analysis. Figure 2S, https://www.raccefyn.co/index.php/raccefyn/article/ downloadSuppFile/422/1990, shows the magnetite powder which is used as raw material in each composite. This magnetite has high distribution of particles sizes and shapes with low aspect ratio; these results are consistent with the works done by Weidenfeller, et al., 2002 and Razzaq, et al., 2007.The aggregates of magnetite particles include large particles sizes $(57 \mu \mathrm{m}-40 \mu \mathrm{m})$, medium particles sizes $(26 \mu \mathrm{m}-12 \mu \mathrm{m})$, and finally small particle sizes $(0.8$ $\mu \mathrm{m}-9 \mu \mathrm{m})$.

Figures 3 and 4 show micrographs of the composites samples in cross sections; they have different magnitudes (50x - 5000x). The powder crystals are bright and are embedded in an opaque polymer matrix. The filled particles size as well as its shape is not uniform. In figures 3 and 4 a wide range of particles sizes: Large particles with sizes between $145 \mu \mathrm{m}$ to $100 \mu \mathrm{m}$, medium particles with sizes from $18 \mu \mathrm{m}$ to $39 \mu \mathrm{m}$, and small particles with sizes from 7 to $0.5 \mu \mathrm{m}$ can be observed. The gap between particles decreases with increasing the filler content and modifying the composite dielectric properties (Weidenfeller, et al., 2002; Razzaq, et al., 2007). In figure 4a for instance, the longest distance between particles in the M20 sample can be greater than $220 \mu \mathrm{m}$; although the average of distances between magnetite particles in the M40 sample is about 17 $\mu \mathrm{m}$ (figure $4 \mathrm{c}$ ). This suggests an increased interconnectivity of the magnetite particles within the polymeric matrix when the filler content is higher, that can explain the prolonged decrease in the volumetric resistivity for the composites with contents equal or greater than $30 \mathrm{vol} \%$ of magnetite powder as it is going to be shown in the next section.

Volumetric resistivity measurements. As it is shown in figure 5 the significant drop (eight orders of magnitude $10^{14}$ to $10^{6}$ ) in the resistivity of composites can be observed between a filler loading of $30 \mathrm{vol} \%$ to $40 \mathrm{vol} \%$ as was predicted in previous works properties (Panwar, et al., 2007; Weidenfeller, et al., 2002; Razzaq, et al., 2007). In contrast, figure 5 shows a high-volume resistivity between the pure HDPE samples and the HDPE samples filled with $20 \mathrm{vol} \%$ of magnetite, that is an indicative of the insulating polymeric phase and the large distances between particles. The samples resistivity can be affected by some factors like the magnetite particles distribution and its interconnectivity into the HDPE matrix, this is why the samples with a low volume fraction of magnetite ( 0 vol \% - 20 vol\%) have a high-volume resistivity, with a low magnetite particles dispersion, so the resistivity is expected to be high and no conductive paths are available between the magnetite particles.

On the other hand, in the samples with the highest filler content (M30-M40) some particles seem to have contacts points among them or are separated only by very small gaps, that produces conducting paths according to the theories of Boettcher (Boettcher, 1952) and Bruggeman (Bruggeman, 1935), this indicates an ideally and homogenous dispersion of the magnetite particles in the polymeric matrix of HDPE. Therefore, charge carriers migrate from one magnetite particle to a neighboring one by hopping or tunneling (Razzaq, et al., 2007). As the work done by Weidenfeller, et al., 2002, who studied the thermal and electrical properties of similar composites materials, it is possible to adopt the model formulated by Boettcher and Bruggeman, in order to calculate the theoretical percolation threshold of this 


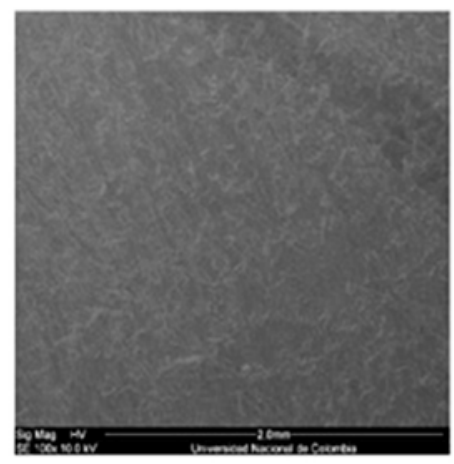

a)

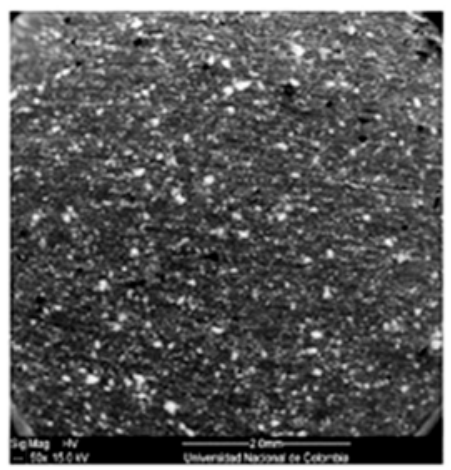

d)

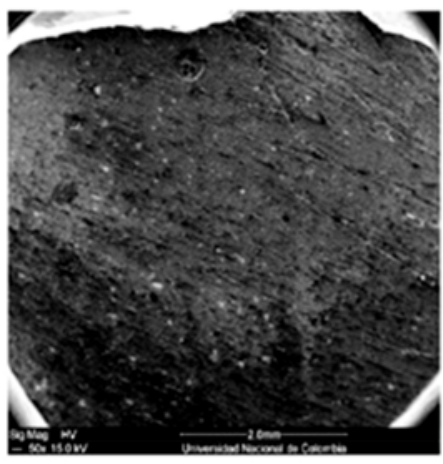

b)

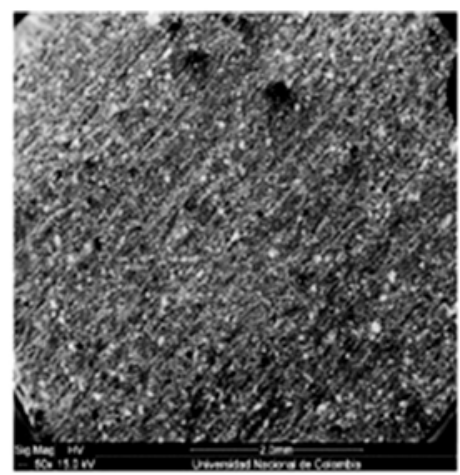

e)

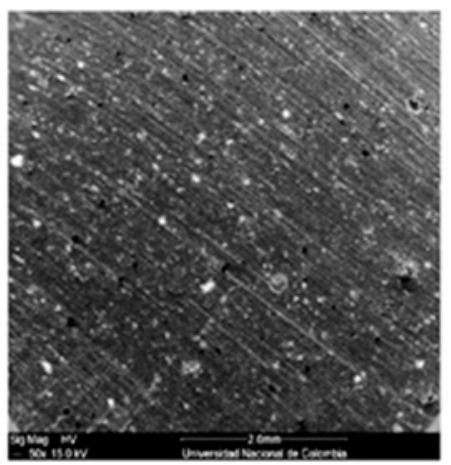

c)

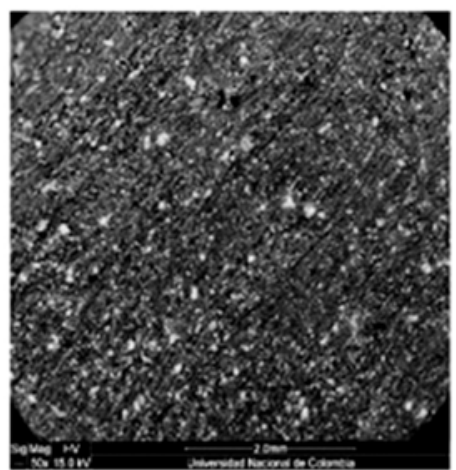

f)

Figure 3. Composites SEM images (50x) with different magnetite ratios in \%vol: a) $0 \%$ b) 10\% c) $20 \%$ d) $30 \%$ e) $35 \%$ f) $40 \%$.

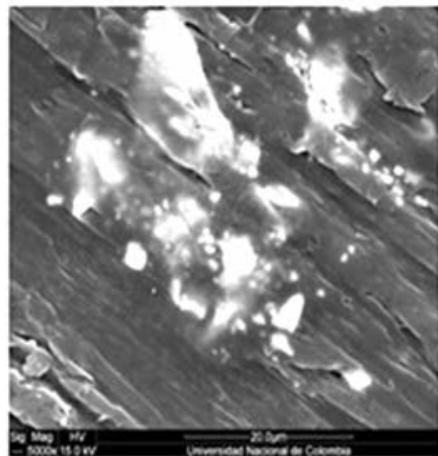

a)

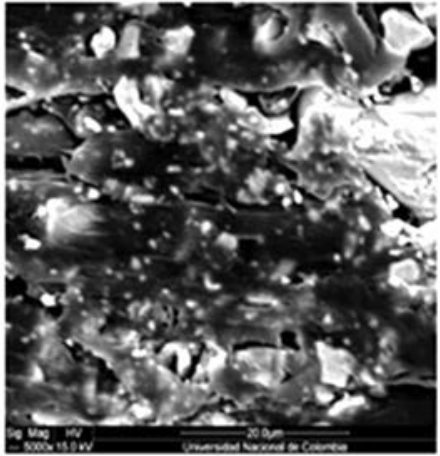

b)

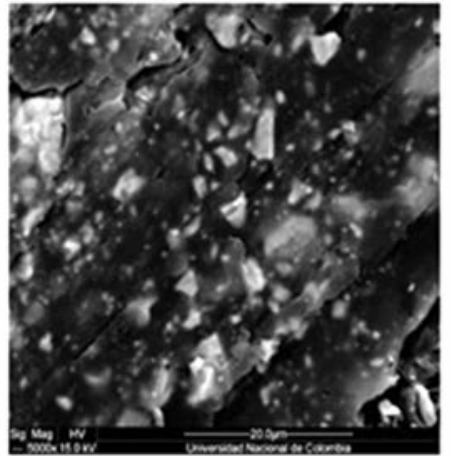

c)

Figure 4. Composites SEM images (5000x) with different magnetite ratios in \%vol: a) 20\% b) 30\% c) $40 \%$.

kind of composites. According to these, the conductivity $\sigma$ in a system comprising by two phases: Phase 1 with a conductivity $\sigma 1$ and a volume fraction $\varphi 1$, and a phase 2 with a conductivity $\sigma 2$ and a volume fraction equal to $\varphi 2=1-\varphi 1$. This can be calculated with the asymmetric Bruggeman equation:

$$
\left(\frac{\sigma}{\sigma_{1}}\right)^{1 / 3} \frac{\sigma_{1}-\sigma_{2}}{\sigma-\sigma_{2}}=\frac{1}{\varphi_{1}}
$$

For the special case of an ideal conductive phase $1(\sigma 1$ $=1)$ and an ideal insulator phase $2(\sigma 2=0)$ the equation above results in a percolation threshold for a phase 1 volume fraction $\varphi 1=0.33$, while for a ratio of conductivities $\sigma 1 / \sigma 2$ $=300$ the percolation threshold is slightly lower with a phase
1 volume fraction of $\varphi 1=0.31$ (Weidenfeller, et al., 2003; Razzaq, et al., 2007; Boettcher, 1952; Bruggeman, 1935).

Both theoretical percolation models were consistent with the experimental results obtained in this work, figure 5 , where the decrease in the volumetric resistivity is evident for samples that contain highest magnetite volumes (>30\%vol).

Electric polarization measurements. The electrical polarization measurements were conducted at room temperature and a triangular wave with a period of $50 \mathrm{~ms}$ was used. Figure 6 shows the polarization curves for the pure HDPE sample, and the M10, M30 and M40 samples, respectively. 


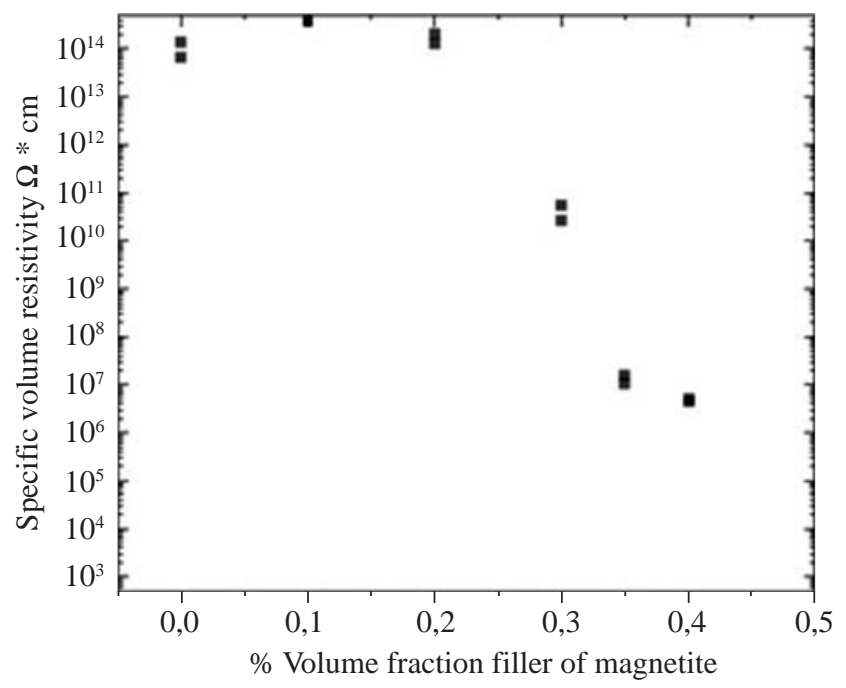

Figure 5. Comparison of the volume resistivity of composites. Samples differ in volume fraction of magnetite particles, and magnetite grades and matrix polymer.

The electrical polarization curve P-E, is a plot of a polarization $(\mathrm{P})$, versus the electric field $(\mathrm{E})$ or voltage $(\mathrm{V})$ applied to the sample at a given frequency. For an ideal linear capacitor, the polarization curve is a straight line whose slope is proportional to the capacitance, since the charge is in phase with the voltage (Stewart \& Cain, 1999). For an ideal
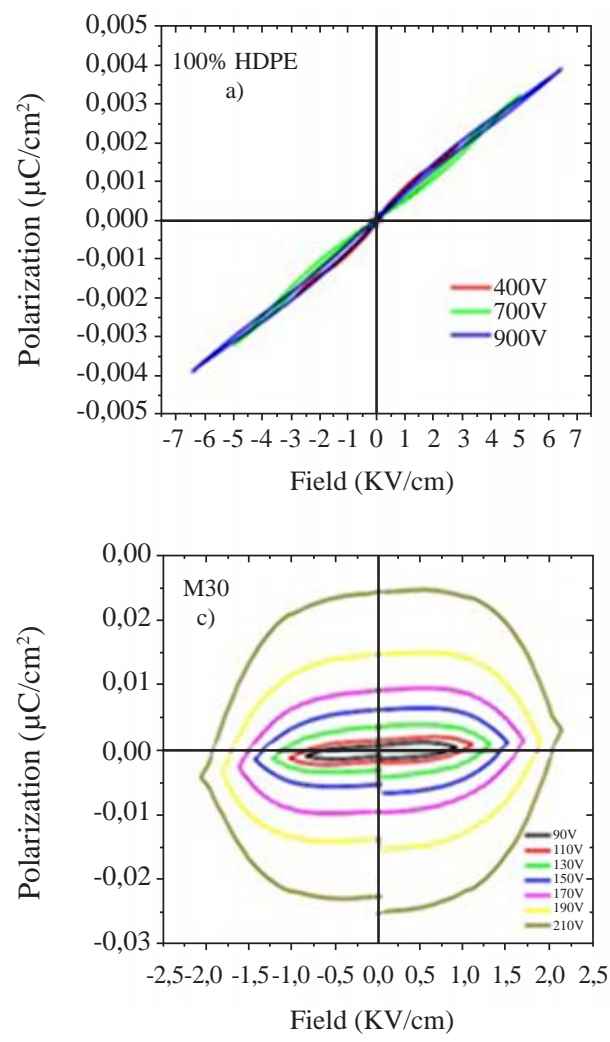

resistance, the P-E curve is a circle centered at the origin, since the current and voltage are in phase, similar to the M30 and M40 P-E curves, figures, $6 \mathrm{c}$ and $6 \mathrm{~d}$. Figure 6 shows how the composite material undergoes a transition going from an insulating material in the M10 sample to a resistive material where the current and voltage are in phase, samples M30 and M40. If these two components are connected in parallel (resistance and linear capacitor), the obtained P-E curve is similar to figure $6 \mathrm{a}$ and $6 \mathrm{~b}$, which relates the behavior of a capacitor with losses, where the slope is proportional to the capacitance and the area within the loop is proportional to the device loss tangent. The breakdown voltage of the HDPE will be significantly reduced when the powdered magnetite is added and its capabilities as an insulating material will be affected. That is the reason why as the magnetite percentage increases the polarization rises even in the presence of low magnitude fields, figures $6 \mathrm{c}$ and $6 \mathrm{~d}$ respectively. As it was seen in the previous section, the dielectric transition behavior matches with the percolation threshold calculated for $33 \%$ vol of magnetite (Boettcher, 1952; Bruggeman, 1935). In the samples with high particle concentrations (< $30 \% \mathrm{vol})$ the electrical conductivity and the dielectric losses increased (Ramajo, et al., 2009). However, this behavior is visible from the sample with $10 \%$ by volume of magnetite. The asymmetric behavior of the P-E curves is due to the electrodes asymmetry used in capacitive structure (Salazar, Landínez \& Roa, 2009).
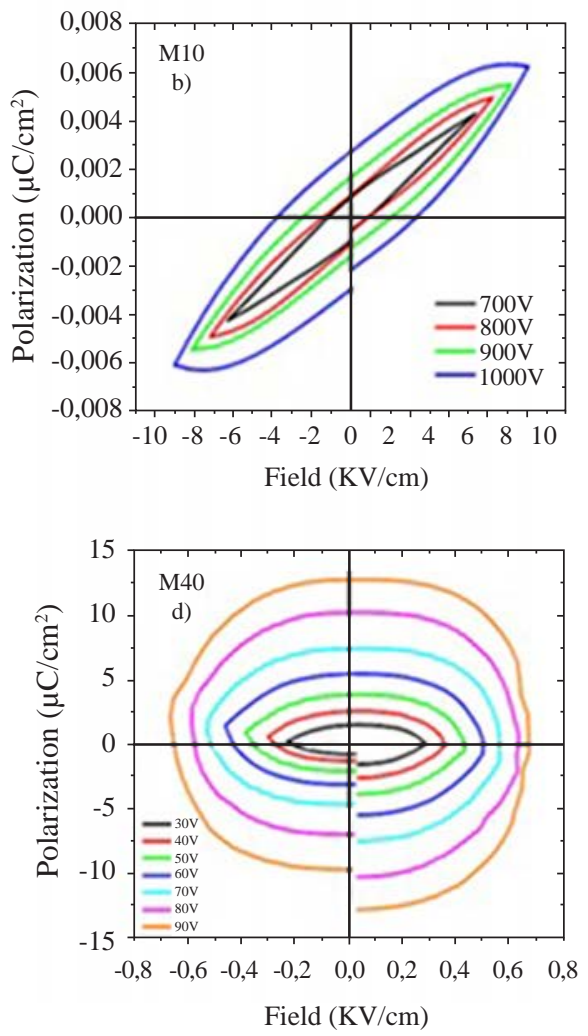

Figure 6. Composites P-F curves a) $100 \% \mathrm{HDPE}$ b) $10 \% \mathrm{Fe}_{3} \mathrm{O}_{4}$ c) $30 \%$ vol. volFe $\mathrm{O}_{4}$ d) $40 \% \mathrm{Fe}_{3} \mathrm{O}_{4}$ 
Rev. Acad. Colomb. Cienc. Ex. Fis. Nat. 41(159):154-167, abril-junio de 2017 doi: http://dx.doi.org/10.18257/raccefyn.422

To calculate the dielectric constants of the pure HDPE and M10 samples, the equation 3.4.1. can be used. The permittivity of an insulating, or dielectric, material $\epsilon$; the permittivity of a vacuum, or free space, $\epsilon 0$; and their ratio is called the dielectric constant $\epsilon \mathrm{r}$ :

$$
\epsilon_{r}=\frac{\epsilon}{\epsilon_{0}}
$$

Equation 3.4.2 relates the surface charge density or electric displacement D and the electric field E applied to a dielectric in a capacitor:

$$
D=\epsilon E
$$

The equation above could be rewritten using the equation 3.4.1, such that the surface charge density D is written in terms of the material dielectric constant, equation 3.4.3:

$$
D=\epsilon_{r} \epsilon_{0} E
$$

In the presence of a dielectric material, electric displacement can be represented as a function of the polarization $\mathrm{P}$ as it is shown in the Equation 3.4.4. Using the equation 3.4.5 it is possible to find the dielectric constant value of the material as a function of the applied electric field and the polarization as it is shown in equation 3.4.5:

$$
\begin{gathered}
D=\epsilon_{0} E+\mathrm{P} \\
\epsilon=1+\frac{P}{\epsilon_{0} E}
\end{gathered}
$$

The values of the polarization saturation and the electric field for the different voltages applied to the pure HDPE and M10 samples were used in order to find the average electric constant value $\left(\epsilon_{\mathrm{r}}\right)$, tables 5 and 6 . The vacuum permittivity

\begin{tabular}{|c|c|c|c|}
\hline Voltage (V) & $\begin{array}{l}\text { Electric Field (E) } \\
\quad(\mathrm{V} / \mathrm{m}) \times 10^{3}\end{array}$ & $\begin{array}{c}\text { Polarization } \\
\text { saturation }\left(\mathbf{P}_{\mathbf{s}}\right) \\
\left(\mathbf{C} / \mathbf{m}^{2}\right) \times 10^{-5}\end{array}$ & $\begin{array}{c}\text { Dielectric } \\
\text { constant } \\
(\epsilon r)\end{array}$ \\
\hline 400 & 285 & 1.97 & 8.81 \\
\hline 700 & 501 & 3.22 & 8.18 \\
\hline \multirow[t]{2}{*}{900} & 643 & 3.89 & 7.83 \\
\hline & Average value & & 8.27 \\
\hline
\end{tabular}
$\left(\epsilon_{0}\right)$ is a constant value $8.8542 \times 10^{-12} \mathrm{~F} / \mathrm{m}$.

Table 5. Dielectric constant value for each voltage used as function of the polarization saturation and the electric field measured for the $100 \%$ HDPE sample.

\begin{tabular}{|c|c|c|c|}
\hline $\begin{array}{c}\text { Voltage } \\
\text { (V) }\end{array}$ & $\begin{array}{l}\text { Electric Field (E) } \\
\quad(\mathrm{V} / \mathrm{m}) \times 10^{3}\end{array}$ & $\begin{array}{c}\text { Polarization } \\
\text { saturation (Ps) } \\
\left(\mathbf{C} / \mathbf{m}^{2}\right) \times 10^{-5}\end{array}$ & $\begin{array}{c}\text { Dielectric } \\
\text { constant } \\
\left(\epsilon_{\mathrm{r}}\right)\end{array}$ \\
\hline 700 & 639 & 4.28 & 8.57 \\
\hline 800 & 723 & 4.92 & 8.69 \\
\hline 900 & 816 & 5.48 & 8.59 \\
\hline 1000 & 908 & 6.22 & 8.74 \\
\hline \multicolumn{3}{|c|}{ Average Value } & 8.65 \\
\hline
\end{tabular}

Table 6. Dielectric constant value for each voltage used as function of the polarization saturation and the electric field measured by the M10 sample.
Production and characterization of a composite material based on $\mathrm{fe}_{3} \mathrm{O}_{4}$ and hdpe.

The average dielectric constant calculated for the HDPE sample is above the normal value registered by manufacturers and suppliers. Since the experimental conditions are different, for instance, the measurement frequency used for the HDPE suppliers in many cases to obtain the dielectric constant is $1 \mathrm{MHz}$, (Matweb, 2014). Resulting in $\varepsilon_{r}$ values of $2-2.5$. Whereas the used frequency in this work never got above the $20 \mathrm{~Hz}$. Even so, the calculated dielectric constant value for the samples 100\% HDPE and $\mathrm{M} 10$ is in the acceptable range of $\varepsilon_{\mathrm{r}}$ at low frequencies for nonconductive plastics such as Bakelite (Meseguer, Gómez, Olmos, Quiles \& Romero, 1995). The slight increase in $\varepsilon_{r}$ between the sample of pure polyethylene and the M10 sample is related to higher polarization values even for the same voltages (Tables 5 and 6). Thus, the addition of powdered magnetite within the plastic matrix allows reaching higher capacitance (C) to the composite.

\section{Magnetization measurements}

Hysteresis curves taken at different temperatures as a function of the magnetic field. Hysteresis curves for all samples are shown in figure 7. Their properties like the saturation magnetization $\left(M_{S}\right)$, remanent magnetization $\left(M_{R}\right)$ and coercively $\left(\mathrm{H}_{\mathrm{C}}\right)$ are shown in table 7 . It is evidenced that for all curves $M_{S}$ and $M_{R}$ decrease as the magnetite proportion decreases within the matrix. These results match with those obtained by (Kong, et al., 2010; Ramajo, et al., 2009; Makled, et al., 2005; Mokhtar, Abdullah \& Ahmad, 2012), in which the saturation magnetization and remanent magnetization values increase as the filler percentage by weight or by volume (either magnetite or some other ferrite) increases. Meanwhile, pure magnetite used as a filler has an experimental magnetic moment of $81.22 \mathrm{emu} / \mathrm{g}$ which is slightly lower than the stoichiometric magnetite that has a magnetic moment of $90 \mathrm{emu} / \mathrm{g}$ at $\approx 300 \mathrm{~K}$ (Buschow, 2014). This value is affected by the particle size, flaws in the crystalline structure that favored the spins random arrangement, and therefore, the presence of a dead layer in the particles surface.

In the previously cited works the increase of $\mathrm{M}_{\mathrm{S}}$ and $\mathrm{M}_{\mathrm{R}}$, due to the increase of the powdered magnetite content in the composite samples, is explained through the probable interaction between the magnetic properties of the magnetite particles within the polymeric matrix (Kong, Ahmad, Abdullah \& Yusoff, 2009). Also, it is determined that the composite saturation magnetization is linearly dependent of the filler mass fraction following the relationship: $M_{S}=$ $M_{F} \times W_{F}$, where $M_{F}$ and $W_{F}$ are the filler magnetization and the filler weight fraction in the composite (Mackled, et al., 2005; Mokhtar, et al., 2012). An aspect to consider in this work and that is not described in previous research that used magnetite as filler in polymeric composites (Weidenfeller, $\boldsymbol{e t}$ al., 2003; Razzaq, et al., 2007; Ramajo, et al., 2009), is the presence of the hematite phase in the samples and that can affect the $M_{S}$ and the $M_{R}$ values in the hysteresis curves. The hematite weight content within the composites is variable 

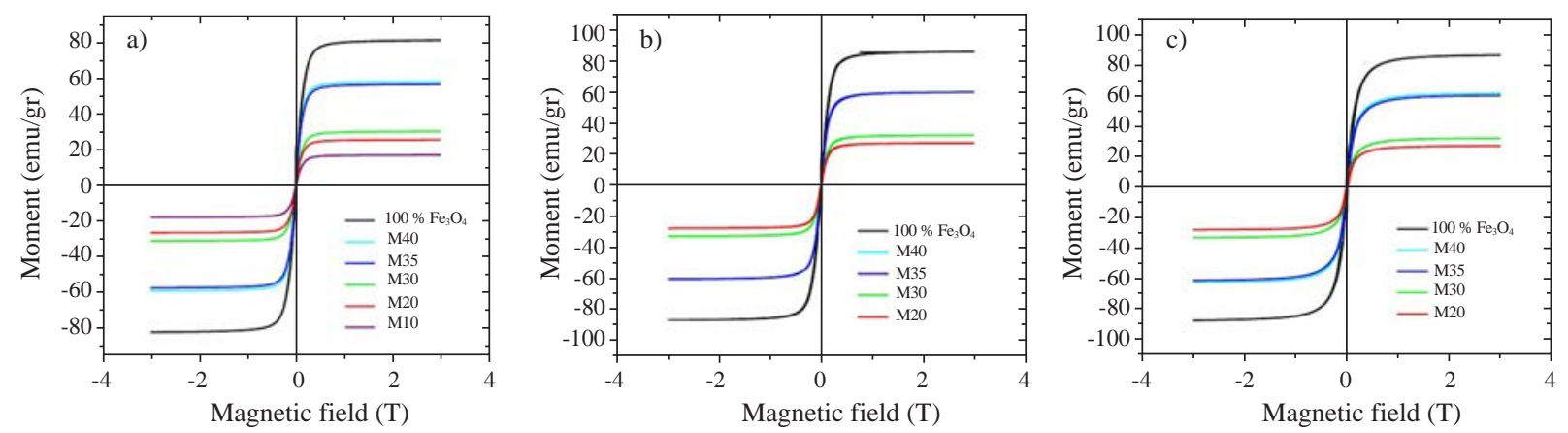

Figure 7. Hysteresis curves taken at different temperatures as a function of magnetic field for each composite sample: a) $300 \mathrm{~K}$, b) $120 \mathrm{~K}$ c) $50 \mathrm{~K}$

Table 7. Magnetic properties of the composite samples at different temperatures: Saturation magnetization $\left(\mathrm{M}_{\mathrm{S}}\right)$, remanent magnetization $\left(\mathrm{M}_{\mathrm{R}}\right)$ and coercivity $\left(\mathrm{H}_{\mathrm{C}}\right)$.

\begin{tabular}{|c|c|c|c|c|c|c|c|c|c|c|}
\hline \multirow[t]{2}{*}{ Sample ID } & \multicolumn{3}{|c|}{$\begin{array}{l}\text { Samples magnetic } \\
\text { properties at } 50 \mathrm{~K}\end{array}$} & \multicolumn{3}{|c|}{$\begin{array}{l}\text { Samples magnetic } \\
\text { properties at } 120 \mathrm{~K}\end{array}$} & \multicolumn{3}{|c|}{$\begin{array}{l}\text { Samples magnetic } \\
\text { properties at } 300 \mathrm{~K}\end{array}$} & \multirow{2}{*}{$\begin{array}{l}\text { Hematite } \\
\% \text { wt in the } \\
\text { sample }\end{array}$} \\
\hline & $\begin{array}{c}M_{\mathrm{s}} \\
(\mathrm{emu} / \mathrm{g})\end{array}$ & $\begin{array}{c}M_{R} \\
(e m u / g)\end{array}$ & $\underset{\mathbf{T}}{\mathbf{H}_{\mathrm{C}}}$ & $\begin{array}{c}M_{\mathrm{s}} \\
(\mathrm{emu} / \mathrm{g})\end{array}$ & $\begin{array}{c}M_{R} \\
(\mathrm{emu} / \mathrm{g})\end{array}$ & $\underset{\mathbf{T}}{\mathbf{H}_{\mathrm{C}}}$ & $\begin{array}{c}M_{\mathrm{s}} \\
(\mathrm{emu} / \mathrm{g})\end{array}$ & $\frac{M_{R}}{(e m u / g)}$ & $\underset{\mathbf{T}}{\mathbf{H}_{\mathrm{C}}}$ & \\
\hline $100 \%$ Magnetite & 86.3 & 8.2 & 0.0179 & 86.2 & 4.5 & 0.00900 & 81.2 & 4.9 & 0.0073 & 12.9 \\
\hline M40 & 61.6 & 8.0 & 0.0196 & 60.1 & 4.3 & 0.01008 & 58.4 & 4.0 & 0.0091 & 20.1 \\
\hline M35 & 59.4 & 7.8 & 0.0185 & 59.7 & 4.3 & 0.01028 & 56.9 & 4.1 & 0.0087 & 20.8 \\
\hline M30 & 32.3 & 4.2 & 0.0179 & 32.2 & 2.5 & 0.01003 & 30.6 & 2.1 & 0.0068 & 24.7 \\
\hline M20 & 26.7 & 3.4 & 0.0181 & 27.2 & 2.0 & 0.01069 & 25.7 & 1.8 & 0.0073 & 39.9 \\
\hline
\end{tabular}

and is related to the used production process (section 2.2). According to Table 7, the weight percentage of the hematite phase is higher for samples with lower percentage by magnetite volume $(10 \%-30 \%)$. Also, this samples exhibit lower $M_{S}$ and $M_{R}$ values for all temperatures. Hematite $\left(\mathrm{Fe}_{2} \mathrm{O}_{3}\right)$ is an iron oxide that crystallizes in a rhombohedral structure and has some particular magnetic properties since although it is classified as an antiferromagnetic material with a Neel temperature $\left(T_{N}=950-960 \mathrm{~K}\right)$, between $263-267 \mathrm{~K}$, it has a magnetic transformation called Morin transition $\left(\mathrm{T}_{\mathrm{M}}\right)$, temperature at which the material passes to be completely antiferromagnetic to present a weak ferromagnetism ( $\mathrm{T}<\mathrm{T}_{\mathrm{M}}$ $<\mathrm{T}_{\mathrm{N}}$ ). Bellow the $\mathrm{T}_{\mathrm{M}}$ temperature the magnetically arranged spins are oriented along the trigonal axis [1 111 l] (C-axis) of the structure, this causes that the hematite behaves as a uniaxial antiferromagnet. Above the $\mathrm{T}_{\mathrm{M}}$ the spins are in the basal plane perpendicular to the axis [ [ $\left.\begin{array}{llll}1 & 1 & 1\end{array}\right]$ except for a slight turn of inclination of the spins outside the basal plane, which gives the material a weak ferromagnetic moment (Zysler, et al., 2001; Stewart, Borzi, Cabanillas , Punte \& Mercader, 2003; Mansilla, Zysler, Fiorani, Suber, 2002). This small magnetic moment generated within the hematite structure has an estimated value of $0.0115 \mu \mathrm{B}$ (Robinson, Harrison, McEnroe \& Hargraves, 2004) which is small compared to the magnetite $4 \mu \mathrm{B}$ (Thapa, Palkar, Kurup \& Malik, 2004), both given as magnetic moments per unit formula (Mpfu).
The composite magnetism is given by the $\mathrm{Fe}_{3} \mathrm{O}_{4}$ which contains an additional phase of $\mathrm{Fe}_{2} \mathrm{O}_{3}$ as it was demonstrated in the quantitative analysis by XRD (section 3.1), and whose weight percentage is modified by the thermal heating during the samples fabrication process. For the hysteresis curves taken at $120 \mathrm{~K}$ and $50 \mathrm{~K}$ (figures $7 \mathrm{~b}-7 \mathrm{c}$ ) hematite behaves like an antiferromagnetic material due to the Morin transition and consequently it does not contribute to the samples magnetic moment, but for the test taken at $300 \mathrm{~K}\left(\mathrm{~T}>\mathrm{T}_{\mathrm{M}}\right)$ hematite can provide a small magnetic moment (which can be obviated if it is compared to the magnetic moment provided by magnetite) because of the parasite or weak ferromagnetism above the $\mathrm{T}_{\mathrm{M}}$.

The coercivity (Hc) behavior is independent of the magnetite reinforcement within the matrix, similar results were presented by Ramajo, et al., 2009 and Guo, et al., 2007, and it's due to the particle size and its random orientation (Mokhtar, et al., 2012). For the hysteresis curves taken at $50 \mathrm{~K}$ and $120 \mathrm{~K}$ the value of the coercive field increases in the samples with lower magnetite content (table 7), indicating that the plastic matrix of HDPE is resistive against the alignment of the magnetic moments of magnetite particles exposed to an external magnetic field (Kong, et al., 2010). In these samples, the distance between the particles also increased and it reduces their interaction, this is an indicator of the material anisotropy that increases with the HDPE matrix increasing (Kong, et al., 2009). 
Some properties in ferro and ferrimagnetic materials as spontaneous magnetization vary with temperature reaching their maximum at $\mathrm{T}=0 \mathrm{~K}$, and have a continuous decrease until they reach 0 in $T_{C}$ or Curie temperature. Magnetite $\mathrm{T}_{\mathrm{C}}$ is $853 \mathrm{~K}$, in that point the material becomes completely paramagnetic. According to figure 7 and table 7, it is possible to observe the saturation magnetization, remanence magnetization and the coercive field tendency decreasing as the temperature increases (Kong, et al., 2009; Donescu, et al., 2012; Demir, Baykal, Sözeri \& Topkaya, 2014; Costa, Ballarin, Spegni, Casoli \& Gardin, 2012; Gu L, He X \& Wu Z , 2014). Using as reference the M40 sample measured at $300 \mathrm{~K}$, the parameters $\mathrm{M}_{\mathrm{S}}, \mathrm{M}_{\mathrm{R}}$ and $\mathrm{H}_{\mathrm{C}}$ decrease by $5.2 \%$, $50 \%$ and $60 \%$ respectively, compared to the same values measured at a $50 \mathrm{~K}$. This is caused by the magnetite thermal spin fluctuations that increase at high temperatures.

Contrary to the low dependence of the coercive field $\mathrm{H}_{\mathrm{C}}$, relative to the magnetite content in the samples, the $\mathrm{H}_{\mathrm{C}}$ decreases as the temperature increases $\left(\mathrm{H}_{\mathrm{C}} 50>\mathrm{H}_{\mathrm{C}} 120>\right.$ $\mathrm{H}_{\mathrm{C}} 300$ ). Table 7 shows a decrease for all samples in the $\mathrm{H}_{\mathrm{C}}$ values up to an order of magnitude for the measurements taken at $300 \mathrm{~K}$ relative to the measurements taken at $50 \mathrm{~K}$. This remarkable fluctuation in the $\mathrm{H}_{\mathrm{C}}$ values can be related to the $\mathrm{T}_{\mathrm{V}}$ temperature $(\approx 120 \mathrm{~K})$ where the Verwey transition takes place. Below the $T_{v}$ the coercivity has much higher values, this is attributed to the discontinuous change in the magnetite anisotropy, going from a symmetrical structural phase as the cubic to a less symmetrical phase like the monoclinic (Bohra, et al., 2009).

Magnetite is considered a superparamagnetic material at room temperature with zero coercive field strength and remanence magnetization, but with a high saturation magnetization value (Costa, 2012; Demir, et al., 2014; Gu, et al., 2014) which makes it desirable for biomedical applications such as targeted drug delivery. This superparamagnetic behavior is partially evidenced by the curves taken at $300 \mathrm{~K}$ (Figure 7a), which clearly show the reduction in the material hysteresis in response to the applied field with a substantial decrease in the $\mathrm{H}_{C}$ and $\mathrm{M}_{\mathrm{R}}$ values. For instance, at 300K M20 sample, it has a $\mathrm{H}_{C}$ and $\mathrm{M}_{\mathrm{R}}$ value of $0.0073 \mathrm{~T}$ and $1.81 \mathrm{emu} / \mathrm{g}$ respectively, but at $50 \mathrm{~K}$, the same one has a $\mathrm{H}_{\mathrm{C}}$ value of 0.017 and $M_{R}$ value of $3.42 \mathrm{emu} / \mathrm{g}$.

Magnetization and susceptibility curves as a function of the temperature. Figure 3S, https://www.raccefyn.co/ index.php/raccefyn/article/downloadSuppFile/422/1992, shows the samples magnetic moment as a function of the temperature $(50 \mathrm{~K}-300 \mathrm{~K})$ exposed to a constant magnetic field of 0.3T. An increase in the material magnetic moment increase as the filler content increase within the HDPE matrix as can be seen, it follows the same trend as the hysteresis curves. The pure magnetite has the greatest magnetic moment and the M10 sample has the lowest magnetic moment, figure 3S, https://www.raccefyn.co/index.php/raccefyn/article/download SuppFile/422/1992. The information about the maximum magnetic moment of each sample (M), temperatures (T) at which these maximum take place (normally associated with the Verwey transition), and the maximum volumetric susceptibilities $\left(\chi_{\mathrm{V}}\right)$ are summarized in table 8 . The dependence of magnetization as a function of the temperature for all samples between 50K and 300K under ZFC (zerofield-cooled) and FC (field cooled) conditions, is also showed in figure 3S, https://www.raccefyn.co/index.php/ raccefyn/article/downloadSuppFile/422/1992. During FC measurements, a magnetic field of $0.3 \mathrm{~T}$ was applied while the sample was cooled to $50 \mathrm{~K}$, then the magnetization was measured while the sample was heated up to $300 \mathrm{~K}$. In the ZFC measurements the sample was cooled to $50 \mathrm{~K}$ without the application of an external magnetic field, and then the magnetization was measured as the temperature increased up to $300 \mathrm{~K}$ under the influence of a magnetic field of $0.3 \mathrm{~T}$. Figure 3S, https://www.raccefyn.co/index.php/raccefyn/ article/downloadSuppFile/422/1992, and table 8 provide relevant information about the composite and magnetite magnetic behavior, before and after the Verwey temperature $\left(\mathrm{T}_{\mathrm{V}}\right.$ ), which was registered from $119 \mathrm{~K}$ to $124 \mathrm{~K}$ (Jackson, Bowles \& Banerjee, 2011). This value can be affected by some factors such as the particle size (Thapa, et al., 2004) or the presence of other phases. The magnetite used in the current study has an irregular particle size (section 3.2) and it contains additional phases as hematite (section 3.1).

Figure 3S, https://www.raccefyn.co/index.php/raccefyn/ article/downloadSuppFile/422/1992, shows how for all samples, the magnetic moment (M) was low at $50 \mathrm{~K}$ and grew slightly to $100 \mathrm{~K}$, then at approximately $120 \mathrm{~K}$ it increased drastically until it reached its maximum value due to the magnetic domains alignment relative to the external field. The magnetite used as precursor in the samples achieved the maximum magnetic moment at $127.66 \mathrm{~K}$, table 8 . The spontaneous reduction in $\mathrm{M}$ below the $120 \mathrm{~K}$ was an indicator of the Verwey transition and was caused by the material structural system transition going from cubic to monoclinic.

Figure 4S, https://www.raccefyn.co/index.php/raccefyn/ article/downloadSuppFile/422/1993, and table 8 show how M10-M40 samples achieved the M maximum value at $129 \mathrm{~K}$ approximately, and it is a result of the irregular particle size

Table 8. Magnetic moment and magnetic susceptibility for each sample as a function of the temperature. $\mathrm{M}$ is the magnetic moment; $\chi_{\mathrm{V}}$ is the magnetic susceptibility and $\mathrm{T}$ the temperature at which the maximum $\mathrm{M}$ is reached.

\begin{tabular}{ccccc}
\hline Sample ID & $\mathbf{M}$ & $\mathbf{T}$ & $\begin{array}{c}\boldsymbol{\chi}_{\mathbf{V}} \\
\mathbf{x 1 0}^{-3}\end{array}$ & $\begin{array}{c}\text { Hematite phase } \\
\text { (wt\%) within } \\
\text { the composite }\end{array}$ \\
\hline 100\% Fe3O4 & 76.81 & 127.66 & 0.38 & 12.9 \\
\hline M40 & 57.27 & 129.19 & 1.19 & 20.1 \\
M35 & 55.54 & 129.41 & 0.58 & 20.8 \\
M30 & 29.96 & 129.85 & 0.30 & 24.7 \\
M20 & 25.60 & 129.90 & 0.13 & 39.9 \\
\hline M10 & 15.59 & 129.96 & 0.10 & 34.1 \\
\hline
\end{tabular}


(figure 2S, https://www.raccefyn.co/index.php/raccefyn/ article/downloadSuppFile/422/1990), a growing presence of the hematite phase and the resistive effect of the HDPE matrix which hinders the magnetic moments alignment of the magnetite particles exposed to an external magnetic field (Kong, et al., 2010). After reaching the maximum value, the samples of the magnetic moment began to drop slightly due to the magnetic moments thermal fluctuations until it reached the Curie temperature $\mathrm{T}_{\mathrm{C}}$ at $\approx 853 \mathrm{~K}$.

The decrease in $\mathrm{M}$ vs. $\mathrm{T}$ curves for temperatures above the TV has a greater slope in samples with higher content of magnetite (Figure 5S, https://www.raccefyn.co/index.php/ raccefyn/article/downloadSuppFile/422/1994), confirming the retarding effect of the HDPE matrix on the magnetic moments alignment. Furthermore, a dramatic growth in the samples magnetization was evidenced, especially for composites with filler contents up to $30 \%$ in magnetite volume. Aspect that was clearly related to the insulatorconductor transition in which the composite undergoes at this filler contents, and that was confirmed through polarization and volume resistivity characterizations (sections 3.3 and 3.4). This jump between the samples magnetic moments as a function of the temperature is associated with the increased proliferation and interaction among the particles as the percentage of magnetite increase within the matrix.

Hematite transitions like the Morin transition unlike magnetite Verwey transition is not easily distinguishable in any of the curves since the hematite magnetization is negligible compared to that provided by the magnetite. The temperature at which the ZFC magnetization curve is detached from the FC curve is known as irreversibility temperature. The taken measurements show discrepancies between the ZFC and FC curves at low temperatures until it joins at the point where the material reaches the maximum $\mathrm{M}$ value, figure 3S, https://www.raccefyn.co/index.php/ raccefyn/article/downloadSuppFile/422/1992. In the ZFC measures the samples were cooled in absence of an external magnetic field and the interactions between particles were reduced. In addition, the random orientation of the magnetic moments resulted in lower magnetization values, that is why the ZFC curve starts with lower magnetization values, but once the external field is applied and the temperature is increased, it is observed that the magnetization starts to growth because the thermal energy released the spins and it allows them to align with the applied field. On the other hand, when the samples were cooled under the magnetic field influence the particles magnetic moment became stabilized under a preferential orientation between them, and impeded the initial alignment with the external field.

The irreversibility temperature is higher for the pure magnetite sample, figure 3S-f, https://www.raccefyn.co/ index.php/raccefyn/article/downloadSuppFile/422/1992, since the ZFC and FC curves never met among them. Generally, the curves separation at high temperatures is the result of the particles large size distribution (Zhang, et al., 2001), such is the case of the filler material used in this study. Even though all samples have the same filler with the same large size particles distribution, the proximity of these due to the plastic matrix improves the magnetic dipoles interaction and cooperates with its preferential orientation relative to an applied external field (Kong, et al., 2009). This close interaction among particles, due to the plastic matrix adhesion, reduces the irreversibility temperature among them, and also promotes the composite magnetization and the magnetic susceptibility.

The samples magnetic susceptibility $(\chi)$, as a function of the temperature, is shown in the figure $6 \mathrm{~S}$, https://www. raccefyn.co/index.php/raccefyn/article/downloadSuppFile/ 422/1995, and in the figure 7S, https://www.raccefyn.co/ index.php/raccefyn/article/downloadSuppFile/422/1996. Small and positive values according to the ferrimagnetic materials behavior are observed $\left(10^{-3}\right)$. All samples reach the magnetic susceptibility maximum value at $125 \mathrm{~K}$ approximately and it is attributed to the magnetite Verwey transition (Zhang, et al., 2001). Like the saturation magnetization, $\chi$ is linearly dependent of the magnetite content within the composite.

The drop in the composites susceptibility at low temperatures is related to the magnetic domains decrease within the magnetite due to its structural change into a monoclinic structure. The boundaries domains movement is responsible for the susceptibility signal, for this reason the large decrease in these domains results in the susceptibility drop as a function of time (Tabiś, et al., 2007).

At the susceptibility, maximum value near to the magnetite $T_{v}$, each magnetite spin should be parallel to the applied field (blocking temperature). This agrees with previous studies that found that by heating the magnetite through the $\mathrm{T}_{\mathrm{V}}$, the magnetic susceptibility may be increased from $20 \%$ up to $80 \%$ (Carporzen Gilder \& Hart, 2006). After reaching the maximum value of $\chi$ and below the magnetite Curie temperature, the $\chi$ as a temperature function follows the relationship: $\chi(T) \propto \mathrm{M}_{\mathrm{s}}(\mathrm{T}) / \mathrm{K}(\mathrm{T})$, where $\mathrm{M}_{\mathrm{S}}$ is the spontaneous magnetization and $\mathrm{K}$ the magnetic anisotropy. Both MS and $\mathrm{K}(\mathrm{T})$ decreased as the temperature increased, so when $T$ approaches to $T_{C}$ both of these factors tend to go to 0 (Harrison \& Putnis, 1996). For this reason, figure 6S, https://www.raccefyn.co/index.php/raccefyn/ article/downloadSuppFile/422/1995, shows how the curves that represent the magnetic susceptibility, after reaching the maximum value, decrease slightly as the samples are heated. At low temperatures, these two effects cancel and $\chi$ remains roughly constant. If $\mathrm{K}$ decreases at a faster rate than MS, thermal fluctuations at $\mathrm{T}$ close to Tc lead to enhance susceptibility. This is known as the Hopkinson effect. Above Tc, MS. is zero and the material displays only paramagnetic susceptibility, which falls to zero rapidly as $\chi \propto 1 /\left(\mathrm{T}-\mathrm{T}_{\mathrm{C}}\right)$.

The pure magnetite sample $\left(100 \% \mathrm{Fe}_{3} \mathrm{O}_{4}\right)$ has the lowest susceptibility value due to factors such as the large particles sizes, wide particles sizes distribution and the lack of interactions between magnetite particles as a result of the no adherence among them. The HDPE plastic matrix 
within the composites promotes the adhesion and therefore the magnetic dipoles interaction and their orientation to an applied magnetic field (Kong, et al., 2009).

The $\chi$ vs $\mathrm{T}$ and the $\mathrm{M}$ vs $\mathrm{T}$ curves for all samples (Figures 3S, https://www.raccefyn.co/index.php/raccefyn/article/ downloadSuppFile/422/1992, 6S, https://www.raccefyn.co/ index.php/raccefyn/article/downloadSuppFile/422/1995), followed the same pattern, the composites susceptibility growths as the magnetite proportion added within the plastic matrix increases due to the augmented interaction between particles. Meanwhile figure 7S, https://www.raccefyn.co/ index.php/raccefyn/article/downloadSuppFile/422/1996, evidences how the M10-M30 samples achieve the $\chi$ maximum value at higher temperatures than the M35 and M40 samples as a result of the irregular particle size, the hematite phase growing presence and the HDPE plastic matrix resistive effect which impede the magnetic moments alignment to the external applied field (Kong, et al., 2010).

\section{Conclusions}

Become Composite samples with different volume ratios of HDPE and magnetite were produced using a single screw extruder machine with three heating zones. The structural and semiquantitative analysis by XRD of the magnetite used as precursor allowed to detecting an additional phase of hematite with a weight percentage of $12.9 \%$. Moreover, the XRD analysis proved the HDPE high degree of crystallinity. Moreover, the composites XRD analysis showed an increased content of hematite phase due to the magnetite unstable nature which readily react with oxygen to become other phases such as hematite at high temperatures. The XRD semiquantitative analysis showed that the samples with high hematite content were those with magnetite contents less than $30 \mathrm{vol} \%$. Since the material flowability and homogeneity along the extrusion screw is higher allowing greater heat transfer to the powder material that promoting the oxidation reaction. It is also confirmed by XRD that there is no chemical reaction between the filler and the HDPE, but rather a mechanical adhesion of the magnetite particles with the polymer matrix, because the characteristic peaks of each material remain constant in every sample diffractogram. The samples peaks intensity reduction or increase as well as its width determined its crystallinity degree $\left(\% \chi_{C}\right)$. It was found that the M10 sample is the sample with the lowest crystallinity and the M40 sample has the highest $\chi_{c}$. Thus, the samples crystallinity degree increases as the magnetite increases within the plastic matrix. Morphological characterization carried out by SEM determined that the magnetite used as precursor has different particle sizes with a low aspect ratio. The composites SEM images showed that as the magnetite content increase within the polymeric matrix the particles are closer to each other. This proximity increased the particles interconnectivity being separated only by small gaps in the HDPE matrix affecting the composites electric and magnetic behavior.
Composites hysteresis curves, as a function of the applied field taken at different temperatures, showed how the saturation magnetization $\left(\mathrm{M}_{\mathrm{s}}\right)$, remanence magnetization $\left(M_{R}\right)$ were linearly dependent of the magnetite content within the HDPE matrix, due to the interaction between the particles magnetic properties, even though the $M_{R}$ and $M_{S}$ values in the hysteresis curves were also affected by the hematite phase in the samples. M10 and M20 samples which have the highest hematite content showed for all temperatures (50K, $120 \mathrm{~K}$ and $300 \mathrm{~K}$ ) the $\mathrm{M}_{\mathrm{S}}$ and $\mathrm{M}_{\mathrm{R}}$ lowest values. The coercivity $\left(\mathrm{H}_{\mathrm{C}}\right)$ has an independent behavior of the samples magnetite content due to the particle size wide distribution and the magnetic moments random orientation. Regarding the temperature effect on the $\mathrm{M}_{S}, \mathrm{M}_{\mathrm{R}}$, and $\mathrm{H}_{\mathrm{C}}$ values, these tend to decrease as the temperature increases, because of the magnetite spins thermal fluctuations, for instance $\left(\mathrm{H}_{\mathrm{C}} 50>\right.$ $\left.\mathrm{H}_{\mathrm{C}} 120>\mathrm{H}_{\mathrm{C}} 300\right)$. The $\mathrm{H}_{\mathrm{C}}$ fluctuations values is related to the magnetite Verwey transition $(\approx 120 \mathrm{~K})$, below this temperature the coercivity higher values are attributed to the magnetite discontinuous anisotropy change going from a symmetrical phase like the cubic structure to a less symmetrical phase as the monoclinic phase. The susceptibility curves $(\chi)$ as a function of the temperature showed small but positive values according to the ferrimagnetic materials behavior. The magnetic susceptibility is higher at $125 \mathrm{~K}$ approximately and it is attributed to the magnetite Verwey transition. Like the saturation magnetization, $\chi$ is linearly dependent of the magnetite content within the HDPE matrix. The composites susceptibility drops at low temperatures before reaching its maximum values and it's related to the magnetic domains decrease due to the monoclinic magnetite structure at these temperatures. At the highest point of the susceptibility curve near to the magnetite $T_{v}$, all the spins that might be aligned parallel to the external applied field were already aligned (blocking temperature). After reaching the susceptibility maximum value and before the magnetite Curie temperature, $\chi$ depends on the spontaneous magnetization and the magnetic anisotropy, both of the decreases as the temperature increase.

The composites electrical characterizations by electrical polarization and volume resistivity measurements showed the composite insulating-conductive transition as the magnetite content increases. The P-E curves evidenced the change the composite had from being an ideal dielectric material (pure HDPE sample) to be a resistor (M40 sample), Meanwhile, the volume resistivity measurements showed a drop of up to eight orders of magnitude from the pure HDPE sample to the M40 sample. The composites electrical properties may be affected by factors such as the wide particle size distribution and the interconnectivity among them. The low dispersion of particles in the magnetite filled HDPE samples between $0 \%$ vol. and $20 \%$ vol. can be the reason for its highs resistivity.

The development of this work confirmed that it is possible to produce a composite material with technological perspectives using abundant and mineral raw materials 
from Colombia which normally are not used for local technical applications. The versatility of the developed composite is such that its own electrical and magnetic properties can fluctuate according to the filler ratio within the polymeric matrix. Thereby, this composite could be used for manufacturing devices where the polymers mechanical properties are required along with variable magnetic and electric characteristics. Materials with these particular specifications are used for transducers, biomedical or electromagnetic shielding devices production.

\section{Acknowledgments}

The research presented herein is made possible by the collaboration of the physic group of new materials (GFNM) subscribed to the National University of Colombia.

\section{Información suplementaria}

Figure 1S. \%Wt magnetite and hematite phases variation according to the volume ratio in the composite. Vea la figura $1 \mathrm{~S}$ en: https://www. raccefyn.co/index.php/raccefyn/article/downloadSuppFile/422/1991 Figure 2S. SEM images of powdered magnetite: a) 1500x b) 3200x c) 5000x. Vea la figura $2 \mathrm{~S}$ en: https://www.raccefyn.co/index.php/ raccefyn/article/downloadSuppFile/422/1990

Figure 3S. Magnetic moment as a function of the temperature for each sample: a) M10, b) M20, c) M30, d) M35, e) M40 and f) $100 \%$ Magnetite. FC (Field cooling); ZFC (zero field cooling). Vea la figura 3S en: https://www.raccefyn.co/index.php/raccefyn/article/ downloadSuppFile/422/1992

Figure 4S. Samples maximum magnetic moments as function of the temperature. Vea la figura $4 \mathrm{~S}$ en: https://www.raccefyn.co/index. php/raccefyn/article/downloadSuppFile/422/1993

Figure 5S. Samples magnetization curves as a function of the temperature. Vea la figura $5 \mathrm{~S}$ en: https://www.raccefyn.co/index. php/raccefyn/article/downloadSuppFile/422/1994

Figure 6S. Susceptibility as a function of the temperature for each sample. Vea la figura $6 \mathrm{~S}$ en: https://www.raccefyn.co/index. php/raccefyn/article/downloadSuppFile/422/1995

Figure 7S. Samples maximum susceptibility as a function of the temperature. Vea la figura $7 \mathrm{~S}$ en: https://www.raccefyn.co/index. php/raccefyn/article/downloadSuppFile/422/1996

\section{Conflicts of interest}

The authors declare that they have no conflict of interest.

\section{References}

Boettcher, C J F. (1952). Theory of electric polarization. Amsterdam: Elsevier.

Bohra M., Prasad S, Venketaramani N, Kumar N, Sahoo S C, Krishnan R. (2009). Magnetic properties of magnetite thin films close to the Verwey transition. Journal of Magnetism and Magnetic Materials. 321 (22): 3738-3741.

Bruggeman, D A G. (1935). Berechnung verschieddener physikalischer konstanten von heterogenen Substanzen. Ann Phys. 24: 636-664.
Buschow, K H J. (2014). Handbook of Magnetic Materials. North Holland: Elsevier B.V.

Carporzen L, Gilder S A, Hart R J. (2006). Origin and implications of two Verwey transitions in the basement rocks of the Vredefort meteorite crater, South Africa. Earth and Planetary Science Letters. 251 (3-4): 305-317.

Costa A L, Ballarin B, Spegni A, Casoli F, Gardini D. (2012). Synthesis of nanostructured magnetic photocatalyst by colloidal approach and spray-drying technique. Journal of colloid and interface science. 388 (1): 31-39.

Demir A, Baykal A, Sözeri H, Topkaya R. (2014). Low temperature magnetic investigation of $\mathrm{Fe} 3 \mathrm{O} 4$ nanoparticles filled into multiwalled carbon nanotubes. Synthetic Metals. 187: $75-80$.

Donescu D, Raditoiu V, Spataru C I, Somoghi R, Ghiurea M, Radovici C, Fierascu R C, Schinteie G, Leca A, Kuncser V. (2012). Superparamagnetic magnetite-divinylbenzenemaleic anhydride copolymer nanocomposites obtained by dispersion polymerization. European Polymer Journal. 48 (10): 1709-1716.

Gu L, He X, Wu Z. (2014). Mesoporous Fe3O4/hydroxyapatite composite for targeted drug delivery. Materials Research Bulletin. 59: 65-68.

Guo Z., Park S, Hahn H T, Wei S, Moldovan M, Karki AB, Young, D P. (2007). Magnetic and electromagnetic evaluation of the magnetic nanoparticle filled polyurethane nanocomposites. Journal of applied physics. 101 (9): 09M511.

Hamoudeh M, Faraj A A, Canet-Soulas E, Bessueille F, Léonard D, Fessi H. (2007). Elaboration of PLLAbased superparamagnetic nanoparticles: Characterization, magnetic behaviour study and in vitro relaxivity evaluation. International Journal of Pharmaceutics. 338 (1-2): 248-257.

Harris L A, Goff J D, Carmichael, A Y, Riffle J S, Harburn J J, St. Pierre T G, Saunders M. (2003). Magnetite Nanoparticle Dispersions Stabilized with Triblock. Copolymers. Chemistry of Materials. 15 (6): 1367-1377.

Harrison R J, Putnis A. (1996). Magnetic properties of the magnetite-spinel solid solution: Curie temperatures, magnetic susceptibilities, and cation ordering. American Mineralogist. 81 (3-4): 375-384.

Jackson M, Bowles J, Banerjee S. (2011). The magnetite Verwey transition (Part A). The IRM Quarterly. 20 (4): 7-10.

Kong I, Hj Ahmad S, Hj Abdullah M, Hui D, Nazlim Yusoff A, Puryanti D. (2010). Magnetic and microwave absorbing properties of magnetite-thermoplastic natural rubber nanocomposites. Journal of Magnetism and Magnetic Materials. 322 (21): 3401-3409.

Kong I, Ahmad S H, Abdullah M H, Yusoff, A N. (2009). The effect of temperature on magnetic behavior of magnetite nanoparticles and its nanocomposites. In AIP Conf Proc. 1136: $830-834$.

Makled M H, Matsui T, Tsuda H, Mabuchi H, El-Mansy M K, Morii, K. (2005). Magnetic and dynamic mechanical properties of barium ferrite-natural rubber composites. Journal of Materials Processing Technology. 160 (2): 229-233.

Mansilla M V, Zysler R, Fiorani D, Suber L. (2002). Annealing effects on magnetic properties of acicular hematite nanoparticles. Physica B: Condensed Matter. 320 (1): 206-209.

Matweb Material Property Data. (November, 2014). Overview of materials for High Density Polyethylene (HDPE). Retrieved from Extruded.: http://www.matweb.com/search/ DataSheet.aspx?MatGUID=482765fad3b443169ec28fb $6 f 9606660$. 
Meseguer Dueñas J M, Gómez Tejedor J A, Olmos Sanchis J J, Quiles Hoyo J, Romero Colomer F. (1995). Problemas resueltos de electromagnetismo y semiconductores. Universidad Politécnica de Valencia: Servicio de Publicaciones SPUPV-99.

Mokhtar N, Abdullah M H, Ahmad S H. (2012). Structural and Magnetic Properties of Type-M Barium FerriteThermoplastic Natural Rubber Nanocomposites. Sains Malaysiana. 41 (9): 1125-1131.

Mücke A, Raphael Cabral A. (2005). Redox and nonredox reactions of magnetite and hematite in rocks. Chemie der Erde - Geochemistry. 65 (3): 271-278.

Otake T, Wesolowski D J, Anovitz L M, Allard L F, Ohmoto H. (2007). Experimental evidence for non-redox transformations between magnetite and hematite under H2-rich hydrothermal conditions. Earth and Planetary Science Letters. 257 (1-2): 60-70.

Panwar V, Sachdev V K, Mehra, R. M. (2007). Insulator conductor transition in low-density polyethylene-graphite composites. European Polymer Journal. 43 (2): 573-585.

Ramajo L A, Cristóbal A A, Botta P M, Porto López J M, Reboredo M M, Castro M S. (2009). Dielectric and magnetic response of Fe3O4/epoxy composites. Composites Part A: Applied Science and Manufacturing, 40 (4): 388-393.

Razzaq M Y, Anhalt M, Frormann, Weidenfeller B. (2007). Thermal, electrical and magnetic studies of magnetite filled polyurethane shape memory polymers. Materials Science and Engineering A. 444 (1-2): 227-235.

Robinson P, Harrison R J, McEnroe S A, Hargraves, R B. (2004). Nature and origin of lamellar magnetism in the hematite-ilmenite series. American Mineralogist. 89 (5-6): 725-747

Rosales C, Perera R, Matos M, Poirier T, Héctor R, Palacios J, et al. (2006). Influencia de la morfología sobre las propiedades mecánicas de nanocompuestos y mezclas de polímeros. Revista Latinoamericana de Metalurgia $Y$ Materiales. 26 (1-2): 3-19.

Salazar Mejía C, Landínez Téllez D A, Roa-Rojas J. (2009). Caracterización Magnetoeléctrica del Nuevo Material de Tipo Perovskita Sr2TiMno6. Revista Colombiana de Física. 4 (2): 317-319.
Stewart S J, Borzi R A, Cabanillas E D, Punte G, Mercader R C. (2003). Effects of milling-induced disorder on the lattice parameters and magnetic properties of hematite. Journal of magnetism and magnetic materials. 260 (3): 447-454.

Stewart M, Cain M G. (1999). Ferroelectric Hysteresis Measurement \& Analysis. NPL Report CMMT(A). 152: 1-57.

Tabiś W, Tarnawski Z, Kąkol Z, Król G, Kołodziejczyk A, Kozłowski A, Honig J. M. (2007). Magnetic and structural studies of magnetite at the Verwey transition. Journal of alloys and compounds. 442 (1): 203-205.

Tadić M, Čitaković N, Panjan M, Stojanović Z, Marković D, Spasojević, V. (2011). Synthesis, morphology, microstructure and magnetic properties of hematite submicron particles. Journal of Alloys and Compounds. 509 (28): 7639-7644.

Thapa D, Palkar V R, Kurup M B, Malik S K. (2004). Properties of magnetite nanoparticles synthesized through a novel chemical route. Materials Letters. 58 (21): 2692-2694.

Weidenfeller B, Höfer M, Schilling F. (2002). Thermal and electrical properties of magnetite filled polymers. Composites Part A: Applied Science and Manufacturing. 33 (8): 10411053.

Zhang J, Rana S, Srivastava R S, Misra, R D K. (2008). On the chemical synthesis and drug delivery response of folate receptor-activated, polyethylene glycol-functionalized magnetite nanoparticles. Acta Biomaterialia. 4 (1): 40-48.

Zhang Z, Church N, Lappe S C, Reinecker M, Fuith A, Saines, P J, Carpenter, M A. (2001). Elastic and anelastic anomalies associated with the antiferromagnetic ordering transition in wüstite, FexO. Journal of Physics: Condensed Matter. 24 (21): 215-404

Zhao H, Saatchi K, Häfeli U O. (2009). Preparation of biodegradable magnetic microspheres with poly(lactic acid)coated magnetite. Journal of Magnetism and Magnetic Materials. 321 (10): 1356-1363.

Zheng X, Zhou S, Xiao Y, Yu X, Li X, Wu P. (2009). Shape memory effect of poly(d,1-lactide)/Fe3O4 nanocomposites by inductive heating of magnetite particles. Colloids and Surfaces B: Biointerfaces. 71 (1): 67-72.

Zysler R D, Vasquez-Mansilla M, Arciprete C, Dimitrijewits M, Rodriguez-Sierra D, Saragovi C. (2001). Structure and magnetic properties of thermally treated nanohematite. Journal of magnetism and magnetic materials. 224 (1): 39-48. 